\section{Mayo new head at Bell Labs}

\section{Washington}

WhEN John Mayo was named the new president of AT\&T Bell Laboratories early this month, he took over one of the world's most famous industrial research laboratories at a pivotal time in its history. In the past year and a half, AT\&T has been shifting the emphasis at Bell Labs towards a more applicationsorientated approach to research, and a number of researchers have left the laboratories amid charges that the days of free-wheeling, anything-goes exploration are rapidly disappearing.

Mayo, who is 61 , seems to have been chosen to move the laboratories into this new role. He himself has moved up through the ranks at Bell Labs over the past 36 years while doing research that lay at the core of AT\&T's business innovations - he worked on the first transistorized digital computer and on digitalizing telecommunications networks, he was a part of the Telstar satellite programme and he has been involved in developing integrated circuits and photonic devices.

"There is a mainstream to the technology" that AT\&T is interested in, Mayo says, and his goal is "a nurturing of research to that mainstream". He insists that he does not want to do anything that will diminish the laboratories' strength in basic research, but researchers there are likely to find their environment changing noticeably over the next few years.

"The principal thing I would want to change is to steadily increase the flow of innovations to the marketplace," Mayo NATIONAL INSTITUTES OF HEALTH Hadley quits two OSI

Washington

In the latest twist in the troubled history of the US National Institutes of Health (NIH)'s Office of Scientific Integrity (OSI), Suzanne Hadley, the OSI's former deputy director, has resigned from the office's two most controversial investigations. Hadley left the OSI in March to take up a post in NIH's Science Policy and Legislation Division. But to provide some continuity, she continued to handle the OSI investigations into the scientific fraud allegedly perpetrated by Tufts University immunologist Thereza Imanishi-Kari, and the disputed claim of National Cancer Institute researcher Robert Gallo to have co-discovered the AIDS virus.

But Hadley resigned from both these investigations on 1 July. "I resigned from the cases because I believed I could no longer be effective and because I no longer had full support [from NIH]," she says. She declines to comment any further, but NIH director Bernadine Healy is widely reported to be annoyed by the editorial says. To do this, he plans to emphasize teamwork, where teams will include everyone from basic researchers to marketing personnel. He foresees "more teams where good basic research is being done as part of a concept or a product or service". This, he says, should make reearchers' jobs more fun because they will see their research applied more quickly.

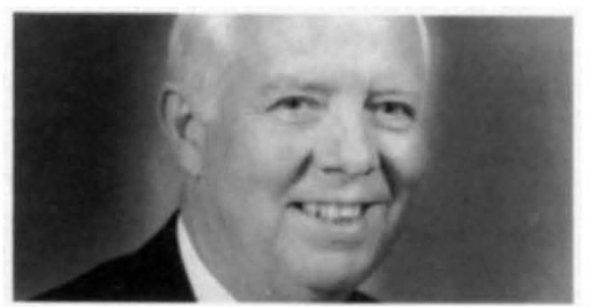

Mayo: eyes on the marketplace

Making research sensitive to market needs will not necessarily squash the creativity and open inquiry that have been Bell Labs' trademarks for decades, Mayo says; indeed, such a sensitivity can stimulate basic research. "When the marketplace became discouraged with vacuum tubes, we got lots of research into materials - it came from the perception of a need," he says. The result was the transistor.

Mayo adds that Bell Labs will still have a place for basic research that has no direct connection with AT\&T products. "We're not diminishing that." Nonetheless, it seems likely that by the time Mayo reaches retirement in a few years, Bell Labs will be a much different place from what it once was.

Robert Pool

\section{investigations}

tone of a widely leaked draft of the OSI's report on the Imanishi-Kari affair, which painted whistleblower Margot $\mathrm{O}^{\prime}$ Toole as the heroine of the case.

The departure of Hadley is likely to bring about Healy's first serious brush with Representative John Dingell (Democrat, Michigan), the formidable congressional watchdog of NIH. Staff at Dingell's House subcommittee on oversight and investigations interviewed Healy, NIH deputy director William Raub and Hadley last week, and have pencilled in a hearing for 31 July to examine Hadley's resignation from the two investigations. Dingell's staff are concerned that Hadley's departure, and with it her knowledge of the history of the two cases, could undermine the OSI's final reports. Although the Imanishi-Kari investigation is almost complete, the key chapter of the Gallo report that includes the results of biological tests on the identity of viral samples central to the case has yet to be written.

\section{NIH quick off the mark}

\section{Washington}

THE US National Institutes of Health (NIH) last week took the unusual step of granting Barr Laboratories a nonexclusive patent licence to market a generic form of AZT, the only fully approved drug for the treatment of AIDS. The move struck some as premature because at this point NIH have no patent rights to AZT, and thus the licence is contingent upon a court deciding that NIH deserve a share of the six AZT-related patents now owned by Burroughs Wellcome.

Barr Laboratories, a generic drug company based in Pomona, New York, is now embroiled in a patent dispute with Burroughs Wellcome of North Carolina. Barr asserts that much of the research that demonstrated AZT's effectiveness against human immunodeficiency virus (HIV) - which in turn led to Burroughs Wellcome being awarded six patents for the use of AZT in the treatment of AIDS in 1988 - was in fact undertaken by researchers at the National Cancer Institute (NCI) and Duke University. Barr contends, therefore, that Wellcome has unfairly reaped the commercial benefits for a drug developed using taxpayer's money (Nature 351, 508; 1991.)

For its part, Wellcome argues that the NIH are trying to rewrite the rules of the cooperative research agreement that the company entered into with $\mathrm{NCI}$ in March 1985 and calls the NIH move "unprecedented". Such actions, the company maintains, could have a chilling effect on research collaborations.

NIH spokesman Don Ralbozski replies that this case over inventorship rights to AZT is likely to be "one of a kind" and says he hopes it will not "impair future collaborations with the private sector", which the NIH are keen to promote.

Even with the NIH licence in hand, Barr has a long way to go to sell a generic form of AZT in the United States. It must first win the court case against Wellcome and then obtain marketing approval by the US Food and Drug Administration for its version of AZT. And if all that goes well, Barr still cannot sell the drug until next July, when Wellcome's rights to sell AZT as an orphan drug run out. (Under the Orphan Drug Act of 1983, companies that develop drugs for the treatment of diseases that affect fewer than 200,000 people receive certain advantages.)

Opening up the market to generic competition could cut the price of AZT - which costs patients between $\$ 2,200$ and $\$ 2,800$ a year - by as much as half, Barr estimates.

Diane Gershon 